\title{
Basal Metabolic Rate
}

National Cancer Institute

\section{Source}

National Cancer Institute. Basal Metabolic Rate. NCI Thesaurus. Code C126083.

A patient's energy expenditure at rest. 